\title{
Türkçe Ders Kitaplarındaki Metinlerin Anlam Yapıları Üzerine Öğrencilerin Özyeterlik Algıları
}

\author{
The Self-Sufficiency Perceptions of Students About The \\ Structures Of Meaning In Texts In Turkish Main Course \\ Books
}

\begin{abstract}
Sezgin DEMIR**, Ahmet Turan SINAN***
Öz: Bu araştırmanın amacı, 6, 7 ve 8 . sınıf Türkçe ders kitaplarındaki metinlerin sözcük ve tümce anlambilim açısından yapısına ilişkin öğrenci görüşlerini, bu metinlerin Türkçe programı ile uygunluğunu belirlemektir. Araştırma, ders kitaplarındaki metinlerin anlam yapılarına iliş̧kin sözcük, tümce ve sözce boyutlarında belirli bir çerçeve belirlemesi açısından önemlidir. Araştırmada ders kitaplarındaki metinlerin anlam yapılarına ilişkin öğrenci görüşlerinin belirlenmesi amaçlanmıştır. $\mathrm{Bu}$ amaçla 31 maddeden oluşan beşli likert tipi bir ölçek hazırlanmış ve bu ölçek Malatya ilinde beş eğitim bölgesinden 15 ortaokulda 6,7 ve 8 . sınıf öğrencilerine uygulanmıştır. Örnekleme sürecinde her bölgeden sosyoekonomik açıdan alt, orta ve üst olmak üzere üçer okul seçilerek toplam 15 ortaokulda araştırma gerçekleştirilmiştir. Bu okullarda eğitim gören toplam ve 1.304 tanesi SPSS programına yüklenerek değerlendirmeye alınmıştır. Elde edilen bulgular benzer çalışmalar ile karşılaştıılarak cinsiyet, sınıf, sosyo-ekonomik yapı, anne ve baba eğitim durumları açısından yorumlanmıştır.
\end{abstract}

Anahtar Kelimeler: Anlam, anlambilim, ders kitabı, dilbilim, Türkçe eğitimi, yazın

\begin{abstract}
The objective of this study is to get the ideas of students in terms of lexical semantics, semantics in clauses in texts in Turkish Course books in 6, 7, 8 grades and to determine the compatibility of these texts with Turkish Programme. At the second phase of the study, it is aimed to determine the opinions of students about meaning structures in texts in course books. Therefore, a questionnaire consisting of 31 items was prepared in accordance with 5-likert type and this questionnaire were applied to students attending 6,7,8 grades in 15 secondary schools located in 5 different regions in province of Malatya. When choosing schools, social-economical situations were taken into consideration and three schools in each region were selected according to low, medium, and upper-leveled social-economical situations. The questionnaire were applied to 1.370 students in these schools and 66 questionnaires were labeled as invalid due to some sorts of reasons and so, 1.304 questionnaires were subjected to evaluation through SPSS program. By comparing the findings with similar studies, they were interpreted in various variables. The research is vital in terms of setting up a specific framework for meaning structures in course books which are one of the most important materials used in teaching mother tongue in which there are words, phrases and statements.
\end{abstract}

Keywords: Meaning, semantics, course book, linguistics, Turkish education, letters

\section{Giriş}

Dil, insanlar arasında iletişimi sağlayan toplumsal bir dizge olup onu, diğer iletişim dizgelerinden ayıran en önemli özelliği ise çift eklemliliğidir. Birinci eklemlilik onun anlam birimlerden oluşan bir yapı olması, ikinci eklemlilik ise onun anlamı olmayan fakat belirli bir işlevi olan ses birimlerden oluşmasıdır. Bu durum sınırlı sayıdaki biçimbirimlerle sınırsız sayıda ifade olanağı sağlamaktadır. Doğal dillerin bir diğer önemli özelliği ise onun toplumsal

\footnotetext{
*Bu makale, Fırat Üniversitesi Eğitim Bilimleri Enstitüsü Türkçe Eğitimi ABD'de Yrd. Doç. Dr. Ahmet Turan SINAN danıșmanlığında yürütülen ve 2014 yılında tamamlanan "Ortaokul $(6,7,8)$ Türkçe Ders Kitaplarındaki Metinlerin Anlam Yapısı ile Bunlara İlişkin Ögrretmen Görüşleri ve Öğrencilerin Özyeterlik Algıları” adlı doktora tezinden hareketle hazırlanmıştır.

**Yrd. Doç. Dr., Fırat Üniversitesi, Eğitim Fakültesi, Elazı̆̆g-Türkiye, e-posta: sezgindemir44@ gmail.com

***Yrd. Doç. Dr., Frrat Üniversitesi, Eğitim Fakültesi, Elazığ-Türkiye, e-posta: atsinan35@ gmail.com
} 
yönüdür. Yani diller toplumsal uzlaşı sonucu ortak bir yapı oluştururlar. Hiçbir birey bilinçli ya da bilinçsiz bu yapıyı değiştiremez, aksine yapısal kurallara uymak zorundadır. Bu toplumsal ve uzlaşımsal dizge, bireyin sosyalleşmesini, aidiyet duygusu geliştirip onu içselleştirmesini, kültür depolayıcısı ve taşıyıcısı olarak kullanılmasını sağlamaktadır. Dil, bir yandan iletişim aracıyken bir yandan da bireyin ulus bilinci kazanmasını sağlamaktadır. Seslerden ve ses eğilimlerinden oluşan ses dizgesi de ana dilinin dış görünümüdür. Buna karşı1ık ana dili; aynı ulustan, aynı dil birliği içindeki kişilere ortak bir evreni anlama ve aktarma yolu kazandıran, zihinsel olarak evreni biçimlendiren bir düşünce dizgesi olarak da işlevsel bir görev üstlenir (Aksan, 2004). Bu durum ana dili eğitiminin önemini bir kez daha ortaya koymaktadır.

Doğal dil dizgesinin birinci eklemlilik özelliği olan ve onu diğer iletişim dizgelerinden ayıran fark, daha küçük anlamlı parçalara ayrılamayan anlam birimlerden oluşmasıdır. Bu noktada ders kitaplarındaki metinlerin çağdaş anlambilimin yöntem ve teknikleri ile çözümlenmesi yararlı olacaktır. Anlam terimi ile kastedilen ise bir biçimbirimin yansıttığı kavramdır. Anlam; dildeki göstergelerin, insanın dünya bilgisine dayalı birtakım belirleyicileri bulunan sözcüklerin belli bir bağlam ve belli bir konum içinde ilettikleri kavramdır (Aksan, 2003, 1997). Bir dildeki anlamlı en küçük birimler, biçimbirimlerdir. Her sözcük aslında bir biçimbirimdir, bunun aksine her biçimbirim bir sözcük değildir. $\mathrm{Bu}$ nedenle anlambilim açısından öncelikle sözcüklerin anlamları ile onların yan anlamları önemlidir. Çünkü daha büyük dilsel ifadelerin anlamları o birimi oluşturan sözcüklerin anlamsal alaşımından oluşmaktadır (Kılıç, 2009). Anlam, bir anlamda dilin derin yapısını oluşturur. Kısacası her dil dizgesi, derin yapıdaki anlamsal boyuttan yüzeysel yapıya doğru bir somutlaşmadır. Derin yapı, birtakım zihinsel işlemlerle -dil bilgisel dönüşümlerle- yüzey yapıya bağlanır ve sonuç olarak da her dil, belirli bir ses-anlam bağıntısı olarak tanımlanabilir (Chomsky, 2002). Bir dilsel gösterge; gösteren ile gösterilen arasındaki eşitlik ilkesinin toplumsal değişmezliği görünümünde oluşmakta, yani ilk olarak gösteren ve gösterilen, bir dilde izdüşümsel olarak görünüp ikinci olarak ise kavram ile ses imgesi aynı devinimlerde üretilir (Coward ve Ellis, 2008). Ses imgesi ile anlam arasındaki bu bağ, her gösterge için bir anlam bulunması kuralının doğal dil dizgeleri için geçerli olmadığının göstergesidir. Her ne kadar ideal bir bildirişme sisteminde her göstergenin belli bir anlamı, her anlam için belli bir gösteren bulunmalı ise de doğal dillerde, kelimelerin anlamındaki kaymalar bir yana eşsüremsel olarak da bir kelime birkaç anlam taşıdığı için bu ilkeye uymaz (Bayrav, 1998). Dilbilimsel açıdan anlam, bir dil biriminin ifade ettiği veya zihinde oluşturduğu düşünce, kavram hatta içerik olarak tanımlanabilir (Erol, 2008). Sonuç olarak anlambilimin en temel konusu olan anlamın ne ifade ettiği ve kapsamı sorunuyla ilgili olarak pek çok görüş ve tartışma bulunmaktadır. Buradan hareketle de birçok akım ortaya çıkmıştır. Bütün bu tartışmalar ve belirsizliklerden hareketle Türkçe ders kitaplarındaki metinlerin sözcük anlambilim, tümce anlambilimi ve edim bilim açısından ele alınmasının bu anlamsal çözümlemeler sonucunda elde edilen verilerin öğretmen ve öğrenci görüşleri ile karşılaştırmalı olarak sınanmasının ana dili eğitimine katkı sağlayacağı düşünülmektedir.

Ana dili, bireyin başta annesi olmak üzere yakın aile çevresinden edindiği okulda elde ettiği bilgilerle geliştirdiği dil olarak tanımlanabilir. İnsanın içerisinde büyüyüp yetiştiği aile veya toplum çevreninden edindiği ilk dildir (Vardar, 2002). Bu durum bir yandan ana dili ile aile ve yakın çevre arasındaki bağı ortaya koyarken bir yandan da okullarda yapılması gerekenin ana dili öğretiminden ziyade eğitiminin gerekliğini ortaya koymaktadır. Çünkü birey, okul sıralarına ana dili edinim sürecinin büyük bir kısmını tamamlamış olarak gelmektedir. Ana dili öğretmeni, yabanc1 dil öğretmeninden farklı olarak öğrencinin kendisinde zaten var olan dilsel alışkanlıkları yenileriyle değiştirmeyi hedeflemez, aksine onları ölçünlü dilin kurallarına uygun şekilde temizlemeyi ve yumuşatmayı hedefler (Marshall, 1994). Ana dili dersi, bireyin öğrenim yaşamındaki en önemli derslerden biridir. Çünkü Türkçe dersleri, bütün derslerin odak noktası ve bilginin kodlandığı ortak dildir. Bu dersin sevilen, zevkli ve verimli bir çalışma alanı olması öğretenlerin başarısını artırırken öğrencilerin de ana dillerini kullanma becerilerini olumlu yönde etkileyecek, bu da doğal olarak diğer derslerdeki başarılarına yansıyacaktır. Bu noktada dil öğretiminde çağdaş üç temel ilkeden söz edilebilir: Bunlardan birincisi dil öğretiminin 
öğrenme durumlarında gerçekleşme, ikincisi etkinlikler yardımıyla yapılma ve son olarak da dil öğretiminde kullanılan her türlü malzemenin anlamlı olma zorunluluğudur (Yıldız, 2003). Özellikle son ilke kullanılan bütün malzemelerin anlamlı olması zorunluluğunu ortaya koymaktadır. Hangi sınıf düzeyinde, hangi metinsel tipte olursa olsun kullanılan bütün metinler, etkinlikler, örnekler, yöntem ve teknikler anlamlı olmalıdır. Aksi halde öğrenci bu dilsel faaliyetleri algılayamayacak, büyük olasılıkla da amaçlanan dilsel beceriye ulaşamayacaktır. Dilbilim, geleneksel dil bilgisinden farklı olarak dil dizgesi içerisindeki bağımlı, bağımsız bütün biçimbirimlerin ses birimlerin ya bir anlamının ya da anlama katkıda bulunan işlevinin olduğunu ortaya koymuştur. Bu nedenle kullanılan metinlerin anlamsal özellikleri son derece önemlidir. Özellikle bu metinler, gerek çocuk yazını gerekse de anlambilim açısından hem ilgili öğrencilerin seviyelerine hem de Türkçe Öğretim Programı'nda yer alan kazanımlara uygun olmalıdır. Ayrıca ana dili eğitimi, bireyin kendi dışındaki bilgileri, çağımız toplumlarında bir kişinin edinmesi gerekli her türlü bilgiyi algılamasına ve anlamasına yarayacak dil öğretimini amaçlayacak şekilde algılamaya yönelik (cognitive); bireyin, iletişim teknolojisini eksiksiz kullanarak kolayca iletişim kurmasını sağlayacak şekilde iletişime (communicative); dil becerilerini davranışlarına yansıtabilmesini sağlayacak nitelikte işlevsel (functional) ve son olarak eleştirel okuma ve dinleme yöntemleriyle eleştirel düşünebilmesi ve bu yolla da düşünme, araştırma, plânlama ve uygulama becerilerini edindirebilecek nitelikte plânlama becerisine yönelik olmalıdır (Yalçın, 2002). Özellikle Türkçe derslerinde kullanılan ders kitaplarındaki metinler seçilirken anlambilimsel açıdan bir bakış açısının henüz geliştirilmemiş olması, metinlerin anlam yapılarına dair çalışmaların azlığı ve yetersizliği söz konusudur. $\mathrm{Bu}$ noktada hedef kitle konumundaki öğrencilerin görüşlerinin alınmasının yararlı olacağ söylenebilir. Türkçe öğretiminde benimsenen yapılandırmacı yaklaşıma göre dili öğrenme, diğer öğrenmeler gibi öğrencinin sorumluluğundadır. Öğrenci dilini yapılandırarak ve uygun durumlarda kullanarak geliştirmeli; öğretmen de bu süreci kolaylaştıracak ortamlar sağlamalıdır: $\mathrm{Bu}$ noktada dil ilk olarak bireyin aktif çabalarıyla; ikinci olarak, bireyin ön bilgilerle yeni bilgiler arasında bağ kurmasıyla, üçüncü olarak tek başına sosyal etkileşmelerle; dördüncü olarak zihinsel becerileri geliştirip zihinsel yapıyı düzenleyerek ve son olarak da gerçek yaşamla ilişkilendirilerek öğrenilir (Güneş, 2007). Dil öğretimine yönelik çağdaş öğretim yöntemi "buldurma ve yeniden yapılandırma" adı verilen işleyiş tarzıdır. Bu yöntemin başlıca aşamaları problem oluşturma, keşfettirerek buldurma, yeniden yapılandırma ve transfer ettirmedir. Bu dil ögretim sürecinin ilk aşamasında farklı sorular yardımıyla çözülmesi gereken sorun, ulaşılması gereken bilgi ya da ortaya çıkarılması gereken kural veya özellikler bütünlüğü öğrencilerin önüne konur; ikinci aşamada daha önceki bilgilerin kullanılması yolu ile dağınık malzemeleri sistemleştirerek yeni sentezlere ulaşmak hedeflenir ve üçüncü aşamada elde edilen yeni bilgilerin daha önceden bulunmuş olanlarla yeniden yapılandırılması ve yeni alanlarda kullanılması söz konusudur ki bu noktada iyi bir ders kitabında bu üç aşamaya uygulanmasına olanak tanıyan metinler yerleştirilmelidir (Cemiloğlu, 2009). Çünkü ana dili eğitiminde kullanılan metinler; ilgi çekici, öğrenci seviyesine uygun, üslubu sağlam ve anlaşılır, sanat değeri taşıyan, kazandırılmaya çalışılan amaca uygun ve kelime serveti bakımından hem zengin hem seviyeye uygun olmalıdır (Nuhoğlu, 2007). Bu bağlamda metinlerin güncel anlambilim yöntem ve tekniklerle sözcük, tümce ve edim boyutunda çözümlenmesi, nitel desende görüşme yöntemiyle betimsel boyutta Türkçe öğretmenlerinin nicel desende de ortaokul 6,7 ve 8 . sinıf ögrencilerinin görüşlerinin alınması, anlam konularının kavratılmasında bir çerçeve belirleyecektir ${ }^{1}$

\section{Araştırmanın Amacı}

$\mathrm{Bu}$ araştırmanın genel amacı; 6, 7 ve 8. sınıf Türkçe ders kitaplarındaki metinlerin sözcük anlambilimi ve tümce anlambilimi açısından yapısına ilişkin öğrenci görüşlerini belirlemektir. $\mathrm{Bu}$ genel amaç çerçevesinde şu sorulara cevap aranmıştır:

\footnotetext{
${ }^{1} \mathrm{Bu}$ makalede sadece metinlerin anlam yapılarına ilişkin öğrenci görüşlerini betimleyen nicel boyutun verileri ele alınmıştır.
} 
1. Metinlerin anlam yapılarına ilişkin öğrenci görüşleri; cinsiyet, sınıf düzeyi, anne ve baba eğitim düzeyleri, sosyoekonomik yapı bakımından anlamlı bir şekilde farklılaşmakta midir?

2. Metinlerin sözcük anlambilimi açısından yapısına ilişkin öğrenci görüşleri; cinsiyet, sınıf düzeyi, anne ve baba eğitim düzeyleri, sosyoekonomik yapı bakımından anlamlı bir şekilde farklılașmakta mıdır?

3. Metinlerin tümce anlambilimi açısından yapısına ilişkin öğrenci görüşleri; cinsiyet, sınıf düzeyi, anne ve baba eğitim düzeyleri, sosyoekonomik yapı bakımından anlamlı bir şekilde farklılaşmakta mıdır?

\section{Yöntem}

\section{Araşturmanin modeli}

Bu araştırma, ortaokul 6, 7 ve 8. sınıf öğrencilerinin Türkçe ders kitaplarındaki metinlerin anlam yapılarına yönelik görüşlerinin belirlenmesi amacıyla nicel desende betimsel tarama modelinde gerçekleştirilmiştir.

\section{Evren ve örneklem}

Araştırmanın evrenini, Malatya il merkezindeki ortaokullar oluşturmaktadır. Örnekleme sürecinde seçkisiz örnekleme yöntemlerinden tabakalı örnekleme kullanılmıştır. Örneklem olarak Malatya il merkezinde biri iyi, biri orta, biri de alt sosyoekonomik düzeye ait olmak üzere her eğitim bölgesinden 3'er okul olmak üzere 15 ortaokulda 1.443 öğrenciden 1.370'ine (\%95) uygulanmıştır. Araştırma kapsamında 6, 7 ve 8. sinıfların her birinden 1'er şube örnekleme dâhil edilmiş; 66 tane ölçek; birden fazla seçeneğin kodlanması, maddelerin işaretlenmemesi veya kişisel bilgi kısmının eksik kodlanması gibi birtakım sebeplerden değerlendirmeye alınmamıştır. Sonuçta 1.304 tane ölçek değerlendirilmiştir.

\section{Veri toplama}

Veri toplama aracı olarak 31 maddelik beşli likert tipi bir ölçek geliştirilmiştir. Alan yazından hareketle geliştirilen taslak ölçek, içerik geçerliği açısından Malatya il merkezinde görev yapan 5 Türkçe öğretmeninin Türkçe Eğitimi ve Eğitim Bilimleri Bölümlerindeki öğretim üyelerinin değerlendirmelerine sunulmuş, maddeler üzerinde birtakım düzeltme ve iyileştirmeler yapılmıştır. KMO değeri .94, Bartlett Testi 4337,988 sonuçları .05 düzeyinde anlamlı bulunması, maddelere faktör analizi uygulanabileceğini göstermektedir. Faktör yüklerinin 32 ile .69 arasında değiştiği, ilk 20 maddenin Cronbach Alpha güvenirlik katsayısı .89, ikinci 11 maddenin .89, ölçeğin bütün olarak Cronbach Alpha güvenirlik katsayısının da .93 olduğu görülmüştür. Spearman_Brown güvenirlik katsayıs1 .87; Guttman split half katsayıs1 .87'dir. Bu sonuçlara göre ölçeğin güvenilir olduğu söylenebilir.

\section{Verilerin Analizi}

Araştırmacının kendisi örnekleme seçilen okullara gitmiş ve ölçeği öğrencilere uygulamıştır. Verilerin analizinde yüzde ve frekans teknikleri, bağımsız gruplar t testi ve varyans analizi; varyans analizinde anlamlı farklılığın kaynağını tespit etmek için scheffe testi kullanılmıştır. Maddelerin gerçekleşme düzeyleri için "Her zaman (4.21-5.00)", "Sık sık (3.41-4.20)", "Bazen (2.61-3.40)", "Nadiren (1.81-2.60)" ve "Hiç (1.00-1.80)" ortalama dereceleri ve değerleri belirlenmiştir.

\section{Bulgular}

$\mathrm{Bu}$ bölümde çalışmanın nicel boyutunda elde edilen bulgular paylaşılmış ve çeşitli değişkenler açısından, benzer çalışmalar ile karşılaştırılması yapılmış ve yorumlanmıştır. 
Türkçe Ders Kitaplarındaki Metinlerin Anlam Yapıları Üzerine Öğrencilerin Özyeterlik Algıları

Tablo 1

Türkçe Ders Kitaplarının Sözcük Anlam Yapılarına İlişkin Öğrenci Görüşlerine Ait Aritmetik Ortalama ve Standart Sapma Sonuçları

\begin{tabular}{|c|c|c|}
\hline \multirow{2}{*}{ Maddeler } & \multicolumn{2}{|c|}{ Öğrenciler } \\
\hline & $\overline{\mathrm{X}}$ & SS \\
\hline $\begin{array}{l}\text { 1. Metinlerde geçen sözcükler arasındaki gerçek anlamlılık özelliğinin } \\
\text { farkına varırım. }\end{array}$ & 4.22 & .93 \\
\hline $\begin{array}{l}\text { 2. Metinlerde geçen sözcükler arasındaki eş anlamlılık özelliğinin } \\
\text { farkına varırım. }\end{array}$ & 4.20 & .97 \\
\hline $\begin{array}{l}\text { 3. Metinlerde geçen sözcükler arasındaki karşıt anlamlılık özelliğinin } \\
\text { farkına varırım. }\end{array}$ & 4.36 & .95 \\
\hline $\begin{array}{l}\text { 4. Metinlerde geçen sözcükler arasındaki çok anlamlılık özelliğinin } \\
\text { farkına varırım. }\end{array}$ & 3.86 & 1.09 \\
\hline $\begin{array}{l}\text { 5. Metinlerde geçen sözcükler arasındaki yan anlamlılık özelliğinin } \\
\text { farkına varırım. }\end{array}$ & 3.74 & 1.16 \\
\hline 6. Metinlerde geçen sesteş sözcüklerin farkına varırım. & 4.03 & 1.14 \\
\hline 7. Metinlerde geçen sözcüklerin kavram alanlarını tespit ederim. & 3.85 & 1.11 \\
\hline $\begin{array}{l}\text { 8. Metinlerde geçen sözcüklerden benim için özel bir değeri olanların } \\
\text { farkına varırım. }\end{array}$ & 4.13 & 1.10 \\
\hline 9. Metinlerde geçen aktarmaların farkına varırım. & 3.82 & 1.16 \\
\hline 10. Metinlerde yer alan benzetme sanatlarının farkına varırım. & 4.08 & 1.09 \\
\hline $\begin{array}{l}\text { 11. Metinlerde geçen özel adların karşıladıkları varlıklar ile olan } \\
\text { anlam ilişkisini tespit ederim. }\end{array}$ & 4.12 & 1.06 \\
\hline $\begin{array}{l}\text { 12. Metinlerden hareketle sözcüklerin, sözcük gruplarının anlamlarını } \\
\text { çıarırım. }\end{array}$ & 3.93 & 1.13 \\
\hline 13. Metinlerde abartılı ifadeleri tespit ederim. & 4.38 & .99 \\
\hline 14. Metinlerde anlam daralmasına uğramış sözcükleri tespit ederim. & 3.64 & 1.22 \\
\hline 15. Metinlerde anlam genişlemesine uğramış sözcükleri tespit ederim. & 3.60 & 1.24 \\
\hline 16. Metinlerde anlam iyileşmesine uğramış sözcükleri tespit ederim. & 3.54 & 1.29 \\
\hline 17. Metinlerde anlam kötüleşmesine uğramış sözcükleri tespit ederim. & 3.75 & 1.26 \\
\hline 18. Metinlerde anlam kaymasına uğramış sözcükleri tespit ederim. & 3.79 & 1.22 \\
\hline 19. Metinlerdeki argo ifadeleri tespit ederim. & 3.93 & 1.38 \\
\hline 20. Metinlerdeki mecazlı ifadeleri tespit ederim. & 4.45 & .98 \\
\hline
\end{tabular}

Toplam $\bar{X}=3.97$

Türkçe ders kitaplarındaki metinlerin sözcük anlambilimi açısından yansıtması gereken temel özelliklerin öğrenciler tarafından nasıl alımlandığına yönelik ders kitaplarının sözcük anlam yapılarına ilişkin, öğrencilere 20 madde yöneltilmiştir. Bu bağlamda öğrenci görüşlerinin "her zaman" ile "sık sık" düzey aralıklarında olması, öğrencilerin sözcük anlambilimi boyutunda üst düzeyde bu dilsel becerilere ulaşabildiklerini göstermektedir. Buna karş1lık dilsel göstergelerin gösterilen kısımlarında dil dizgesinin tümelliğine de yansıyan ve artsüremsel bakış açısını gerekli kılan anlam değişmelerinin tespitine dair öğrencilerin daha düşük düzeyde görüş belirtmeleri dikkat çekicidir. Metinlerin sözcük anlambilimi yapılarına ilişkin öğrenci görüşlerinin toplam aritmetik ortalaması ise "sık s1k" (3.97) düzeyindedir. Buradan hareketle öğrencilerin ders kitaplarını, sözcük anlambilimi açısından "sık sık" düzeyinde etkili buldukları söylenebilir.

Tablo 2

Cinsiyete Göre Sözcük Anlamı Becerilerine İlişkin t Testi Sonuçları

\begin{tabular}{ccccccc}
\hline Cinsiyet & $\mathrm{n}$ & $\overline{\mathrm{X}}$ & $\mathrm{ss}$ & $\mathrm{sd}$ & $\mathrm{t}$ & $\mathrm{p}$ \\
\hline $\mathrm{K} 1 \mathrm{z}$ & 606 & 4.08 & .64 & 1302 & 5.209 & .000 \\
\cline { 5 - 6 }
\end{tabular}


$\begin{array}{llll}\text { Erkek } & 698 & 3.88 & .71\end{array}$

Tablo 2'deki bulgulara bakıldığında Türkçe ders kitaplarındaki metinlerin sözcük anlambilmine ilişkin görüşlerin cinsiyet değişkeni açısından farklılaştığı tespit edilmiştir $[\mathrm{t}(1302)=-5,209 ; \mathrm{p}<.05]$. Aritmetik ortalamalar1 bak1mından ise k1z (4.08) ve erkek (3.88) öğrenciler, "sık sık" düzeyinde görüş belirtmişlerdir. Bu durum öğrenci görüşlerinin metinlere ilişkin görüşlerinin olumlu olduğunu göstermektedir. Ayrıca kız öğrencilerin erkeklere göre metinleri daha olumlu buldukları görülmektedir.

Tablo 3

Sınıf Düzeyine Göre Sözcük Anlamı Becerilerine İlişkin Öğrenci Görüşlerine Ait Varyans Analizi Sonuçları

\begin{tabular}{|c|c|c|c|c|c|c|c|c|c|c|}
\hline Sınıf Düzeyi & $\mathrm{n}$ & $\overline{\mathrm{X}}$ & ss & VK & KT & sd & $\mathrm{KO}$ & $F$ & p & Fark \\
\hline 6. sinif & 459 & 4.14 & .63 & $\begin{array}{c}\text { Gruplar } \\
\text { Aras1 }\end{array}$ & 20.657 & 2 & 10.328 & & & \\
\hline 7. sinif & 448 & 3.90 & .66 & $\begin{array}{c}\text { Gruplar } \\
\text { İçi }\end{array}$ & 589.066 & 1301 & .453 & $22.811 *$ & .000 & $\begin{array}{l}6-7 \\
6-8\end{array}$ \\
\hline 8. sinif & 397 & 3.85 & .74 & Toplam & 609.723 & 1303 & & & & \\
\hline
\end{tabular}

Tablo 3'teki varyans analizi sonucu, sınıf değişkeni bakımından metinlerin sözcük anlambilimi yapısı aşamasına ilişkin öğrenci görüşlerinin anlamlı şekilde farklılaştığını ortaya koymaktadır $[F(2-1301)=22.811 ; p<.05]$. Scheffe testi sonucunda farklılaşmanın 6 . sınıf (4.14) ile 7.sınıf (3.90) ve 8. sınıf (3.85) öğrencileri arasında olduğu tespit edilmiştir. Ayrıca 6. sınıf öğrencilerinin görüşlerinin diğerlerine göre daha olumlu olduğu söylenebilir. Sınıf seviyesi yükseldikçe öğrenciler, sözcük anlambilimi açısından metinleri daha yetersiz olarak değerlendirmektedir.

Tablo 4

Okulun Sosyoekonomik Düzeyine Göre Sözcük Anlamı Becerilerine İlişkin Öğrenci Görüşlerine Ait Varyans Analizi Sonuçları

\begin{tabular}{|c|c|c|c|c|c|c|c|c|c|c|}
\hline Sosyo-Ekon. & $\mathrm{n}$ & $\overline{\mathrm{X}}$ & ss & VK & KT & $\mathrm{sd}$ & KO & $\mathrm{F}$ & $\mathrm{p}$ & Fark \\
\hline İyi & 501 & 4.05 & .65 & $\begin{array}{c}\text { Gruplar } \\
\text { Aras1 }\end{array}$ & 5.262 & 2 & 2.631 & & & \\
\hline Orta & 443 & 3.95 & .66 & $\underset{\text { İci }}{\text { Gruplar }}$ & 604.461 & 1301 & 465 & $5.662 *$ & .004 & Alt-İyi \\
\hline Alt & 306 & 3.89 & .74 & Toplam & 609.723 & 1303 & & & & \\
\hline
\end{tabular}

Tablo 4'teki varyans analizi sonucu, sosyoekonomik yapı değişkeni açısından öğrencilerin Türkçe ders kitaplarındaki metinlerin sözcük anlambilimi yapısına ilişkin görüşlerinin anlamlı biçimde farklılaştı̆ııı göstermektedir $[\mathrm{F}(2-1301)=5,662 ; \mathrm{p}<.05]$. Gerçekleştirilen Scheffe testi farklılaşmanın sosyoekonomik yapı bakımından alt (3.89) ile iyi (4.05) düzeyleri arasında gerçekleştiğini göstermektedir. Elde edilen bu bulgu sosyoekonomik yapı düzeyi yükseldikçe metinlerin sözcüksel anlam yapılarına ilişkin anlaşılırlık düzeylerinin arttığı söylenebilir. Buna karşılık her üç sosyoekonomik düzeydeki öğrenci grubu da "sık sık" düzeyinde görüş bildirmişlerdir. 
Tablo 5

Anne Eğitim Düzeyine Göre Sözcük Anlamı Becerilerine İlişkin Öğrenci Görüşlerine Ait Varyans Analizi Sonuçları

\begin{tabular}{|c|c|c|c|c|c|c|c|}
\hline $\begin{array}{l}\text { Anne Eğitim } \\
\text { Durumu }\end{array}$ & $\begin{array}{lll}n & \bar{X} & \text { ss }\end{array}$ & VK & KT & sd & $\mathrm{KO}$ & $\mathrm{F}$ & Fark \\
\hline Okuryazar Değil & 1173.79 .71 & Gruplar & 130 & 5 & 26 & \multirow{6}{*}{\multicolumn{2}{|c|}{$\begin{array}{c}\text { Okuryazar Değil-Lise } \\
\text { Okuryazar Değil- } \\
\text { E. Üniversite } \\
\begin{array}{c}\text { Okuryazar-Üniversite } \\
\text { İlkokul-Üniversite }\end{array}\end{array}$}} \\
\hline Okuryazar & 793.85 .83 & Aras1 & 10. & $J$ & 2.011 & & \\
\hline İlkokul & 4983.94 .65 & Grounl & & & & & \\
\hline Ortaokul & 2903.97 .68 & & & & . 400 & & \\
\hline Lise & 2394.06 .67 & Toplam & 609.723 & 1303 & & & \\
\hline Universite & 814.24 .65 & & & & & & \\
\hline
\end{tabular}

Tablo 5'teki varyans analizi sonucu, annenin eğitim durumu değişkeni açısından Türkçe ders kitaplarındaki metinlerin sözcük anlambilimi yapısı aşamasına ilişkin öğrenci görüşleri anlamlı şekilde farklılaşmaktadır $[\mathrm{F}(5-1298)=5.681 ; \mathrm{p}<.05]$. Scheffe testi; farklılaşmanın okuryazar değil (3.79) ile lise (4.06) ve üniversite mezunları (4.24) arasında gerçekleştiğini göstermektedir. Bunlardan okuryazar olmayanların çocukları ile lise mezunu olanların çocukları "s1k s1k" düzeyinde görüş belirtirken, üniversite mezunu olanların çocukları "her zaman" düzeyinde görüş belirtmişlerdir. Yine üniversite mezunu (4.24) ile okuryazar değil (3.79), okuryazar (3.85) ve ilkokul (3.94) düzeyleri arasında anlamlı bir farklılaşma tespit edilmiştir. Üniversite mezunlarının çocuklarının "her zaman"; okuryazar olmayan, okuryazar olan ve ilkokul mezunu annelerin çocuklarının "sık sık" düzeyinde görüş belirttikleri görülmektedir. Bu bulgular değerlendirildiğinde iki yönden anlamlı farklılaşma görülmektedir. Üniversite mezunu olanların çocuklarının, okuryazar olmayan, okuryazar olan ve ilkokul mezunu olanlara göre daha olumlu; okuryazar olmayan annelerin çocuklarının, lise ve üniversite mezunu olan annelerin çocuklarına göre daha olumsuz görüşlere sahip oldukları görülmektedir. Anne eğitim düzeyi yükseldikçe metinleri alımlama seviyelerinin arttığı söylenebilir.

Tablo 6

Baba Eğitim Düzeyine Göre Sözcük Anlamı Becerilerine İlişkin Öğrenci Görüşlerine Ait Varyans Analizi Sonuçları

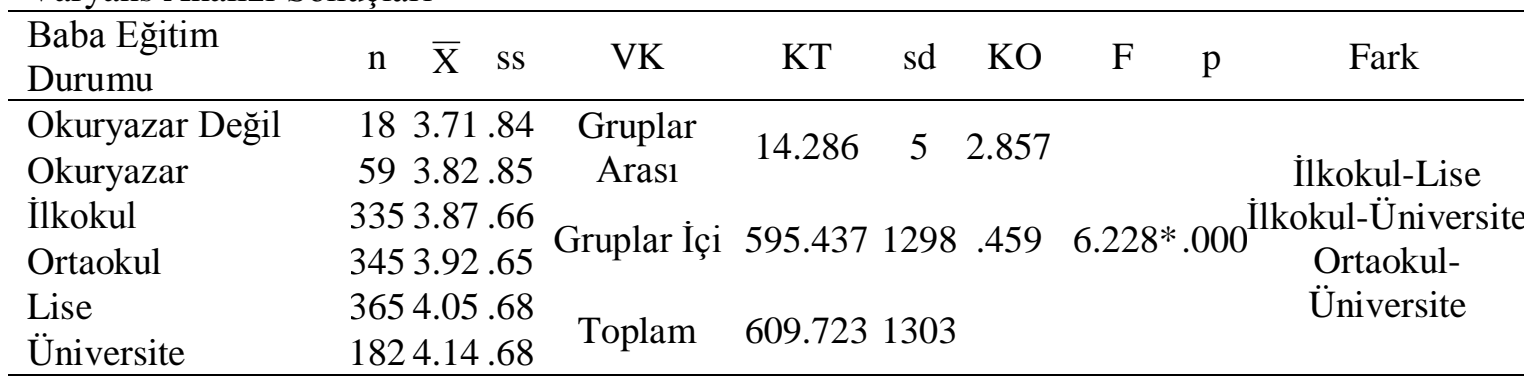

Tablo 6' da, babanın eğitim durumu değişkeni açısından öğrencilerin metinlerin sözcük anlambilimi açısından yapısına ilişkin görüşlerinin anlamlı şekilde farklılaştığını göstermektedir $[F(5-1298)=6.228 ; p<.05]$. Scheffe testi, farklılaşmanın baba eğitim durumu bakımından ilkokul (3.87) ile lise (4.05) ve üniversite mezunlarının çocukları (4.14) arasında gerçekleştiğini göstermektedir. İlkokul, lise ve üniversite mezunu babaların çocukları da "sık sı1" düzeyinde görüş belirttikleri tespit edilmiştir. Üniversite (4.14) ile ilkokul (3.87) ve ortaokul (3.92) düzeyleri arasında anlamlı bir farklılaşmanın olduğunu görülmektedir. $\mathrm{Bu}$ üç eğitim durumu açısından da "sık sık" düzeyinde görüş belirtildiği görülmüştür. Sonuç olarak babanın eğitim düzeyi arttıkça, tıpkı anne eğitim düzeyinde olduğu gibi, çocukların başarı durumlarının paralel bir şekilde arttı̆̆ 1 belirlenmiştir. Bu noktada eğitim durumu bakımından üniversite mezunu olan babaların çocuklarının; diğerlerine göre ders kitaplarındaki metinleri, sözcük anlambilimi 
açısından daha olumlu değerlendirdikleri söylenebilir.

Tablo 7

Türkçe Ders Kitaplarının Tümce Anlam Yapılarına İlişkin Öğrenci Görüşlerine Ait Aritmetik Ortalama ve Standart Sapma Sonuçları

\begin{tabular}{|c|c|c|}
\hline \multirow{2}{*}{ Maddeler } & \multicolumn{2}{|c|}{ Öğrenciler } \\
\hline & $\overline{\mathrm{X}}$ & ss \\
\hline 21. Metinlerde gecen olumlu cümleleri tespit ederim. & 4.57 & .82 \\
\hline 22. Metinlerde gecen olumsuz cümleleri tespit ederim. & 4.44 & .90 \\
\hline 23. Metinlerde gecen soru cümlelerini tespit ederim. & 4.48 & .91 \\
\hline 24. Metinlerde geçen duyguları karșilayan ünlem cümlelerini tespit ederim. & 4.49 & .91 \\
\hline 25. Metinlerde sart belirten cümleleri tespit ederim. & 4.26 & .98 \\
\hline 26. Metinlerde istek belirten cümleleri tespit ederim. & 4.30 & .99 \\
\hline 27. Metinlerde emir cümlelerini tespit ederim. & 4.27 & 1.03 \\
\hline 28. Metinlerde gereklilik bildiren cümleleri tespit ederim. & 4.20 & 1.04 \\
\hline 29. Metinlerdeki karşılıklı konuşmalarda konuşmacının niyetinin farkına varırım. & 4.18 & 1.03 \\
\hline $\begin{array}{l}\text { 30. Metinlerdeki karşılıklı konuşmalarda konuşmacının etkili konuşma } \\
\text { yöntemlerinin farkına varırım. }\end{array}$ & 4.31 & .97 \\
\hline 31. Metinlerdeki karşılıklı konuşmalarda doğru cümlelerin farkına varırım. & 4.24 & 1.04 \\
\hline
\end{tabular}

Toplam $\bar{X}=4.34$

Ders kitaplarındaki metinlerin tümce anlambilimine yönelik olarak araştırmaya katılan öğrencilere TÜDÖP ile ilişkili olarak 11 madde yöneltilmiştir. Katılımcılar; olumlu (4.57), olumsuz (4.44), soru (4.48), ünlem (4.49), şart belirten (4.26), istek belirten (4.30), emir (4.27), gereklilik bildiren cümleleri tespit etme (4.20); konuşmacının niyetinin ve tutumunun (4.18), etkili konuşma yöntemlerinin (4.31), açık, yeterli ve doğru cümlelerin farkına varma (4.24) dilsel becerilerine yönelik "her zaman" düzeyinde görüş belirtmişlerdir. Metinlerin tümce anlambilimi yapılarına ilişkin toplam aritmetik ortalama "her zaman" (4.34) düzeyindedir. Bu durum, öğrencilerin metinleri, tümce anlambilimi açısından sözcük anlambilimine göre daha olumlu bulduklarını göstermektedir.

Tablo 8

Cinsiyete Göre Cümle Anlam Becerilerine İlişkin t Testi Sonuçları

\begin{tabular}{ccccccc}
\hline Cinsiyet & $\mathrm{n}$ & $\overline{\mathrm{X}}$ & $\mathrm{ss}$ & $\mathrm{sd}$ & $\mathrm{t}$ & $\mathrm{p}$ \\
\hline Kiz & 606 & 4.48 & .58 & \multirow{2}{*}{1302} & \multirow{2}{*}{6.976} & \multirow{2}{*}{.000} \\
Erkek & 698 & 4.22 & .72 & & & \\
\hline
\end{tabular}

Tablo 8'de metinlerin tümce anlambilimine ilişkin görüşlerin cinsiyet değişkeni açısından anlamlı bir şekilde farklılaştığı belirlenmiştir [t(1302)=-6,976; $\mathrm{p}<.05]$. Araştırmaya katılan grupların aritmetik ortalamaları ise kızlarda (4.48), erkeklerde (4.22) şeklinde belirlenmiştir. $\mathrm{Bu}$ sonuç görüşlerin "her zaman" düzeyinde şekillendiğini göstermektedir. Buradan hareketle kız öğrencilerin metinleri, tümce anlambilimi açısından daha olumlu buldukları söylenebilir.

Tablo 9

Sınıf Düzeyine Göre Tümce Anlamı Becerilerine İlişkin Öğrenci Görüşlerine Ait Varyans Analizi Sonuçları

\begin{tabular}{ccccccccccc}
\hline Sinıf Düzeyi & $\mathrm{n}$ & $\overline{\mathrm{X}}$ & $\mathrm{ss}$ & $\mathrm{VK}$ & $\mathrm{KT}$ & $\mathrm{sd}$ & $\mathrm{KO}$ & $\mathrm{F}$ & $\mathrm{p}$ & Fark \\
\hline 6. sinıf & 459 & 4.47 & .56 & $\begin{array}{c}\text { Gruplar } \\
\text { Arası }\end{array}$ & 12.917 & 2 & 6.458 & $14.624^{*}$ & .000 & $6-7$ \\
7. sinıf & 448 & 4.29 & .66 & $\begin{array}{c}\text { Gruplar } \\
\text { İçi }\end{array}$ & 574.569 & 1301 & .442 & & &
\end{tabular}


8. sinif $\quad 397 \quad 4.24 \quad .77 \quad$ Toplam $\quad 587.486 \quad 1303$

Tablo 9'da sınıf düzeyi değişkenine göre metinlerin tümce anlambilimi açısından yapısına ilişkin görüşlerin anlamlı biçimde farklılaştı̆̆ görülmektedir [F(2-1301)=14.624; p<.05]. Scheffe testi farklılaşmanın 6. sınıf (4.47) ile 7.sınıf (4.29) ve 8. sınıf (4.24) öğrencileri arasında gerçekleştiğini göstermektedir. Buradan hareketle 6. sınıf öğrencilerinin metinleri, tümce anlambilimi açısından daha olumlu buldukları söylenebilir. $\mathrm{Bu}$ durum sınıf düzeyi yükseldikçe öğrencilerin tümce anlambilimine yönelik dilsel özelliklerinin daha düşük düzeyde kaldığını göstermektedir.

Tablo 10

Okulun Sosyoekonomik Düzeyine Göre Tümce Anlamı Becerilerine İlişkin Öğrenci Görüşlerine Ait Varyans Analizi Sonuçları

\begin{tabular}{|c|c|c|c|c|c|c|c|c|c|c|}
\hline Sosyo-Ekon. & $\mathrm{n}$ & $\overline{\mathrm{X}}$ & Ss & VK & KT & sd & $\mathrm{KO}$ & $\mathrm{F}$ & $\mathrm{p}$ & Fark \\
\hline İyi & 501 & 4.43 & .62 & $\begin{array}{c}\text { Gruplar } \\
\text { Aras1 }\end{array}$ & 7.441 & 2 & 3.721 & & & \\
\hline Orta & 443 & 4.31 & .65 & $\underset{\text { İci }}{\text { Gruplar }}$ & 580.045 & 1301 & .446 & $8.345^{*}$ & .000 & $\begin{array}{l}\text { Alt-ly1 } \\
\text { Orta-İyi }\end{array}$ \\
\hline Alt & 360 & 4.25 & .75 & Toplam & 587.486 & 1303 & & & & \\
\hline
\end{tabular}

Tablo 10'da sosyoekonomik yapı değişkeni açısından öğrencilerin Türkçe ders kitaplarındaki metinlerin tümce anlambilimi açısından yapısına ilișkin görüșlerinin anlamlı şekilde farklılaştığı görülmektedir $[\mathrm{F}(2-1301)=8.345 ; \mathrm{p}<.05]$. Scheffe testi farklılaşmanın sosyoekonomik yapı bakımından iyi (4.43) ile orta (4.31) ve alt (4.25) düzeyler arasında olduğunu göstermektedir. Elde edilen bu bulgu sosyoekonomik yapı bakımından üst düzeydeki öğrencilerin metinleri, alt düzeyde olanlara göre daha olumlu bulduklarını göstermektedir. Buna karşıllk her üç sosyoekonomik düzeydeki öğrenci grubunun da "her zaman" düzeyinde görüş bildirdikleri belirlenmiştir.

Tablo 11

Anne Eğitim Düzeyine Göre Tümce Anlamı Becerilerine İlişkin Öğrenci Görüşlerine Ait Varyans Analizi Sonuçları

\begin{tabular}{|c|c|c|c|c|c|c|c|}
\hline $\begin{array}{l}\text { Anne Eğitim } \\
\text { Durumu }\end{array}$ & n $\quad \bar{X}$ ss & VK & KT & sd & $\mathrm{KO}$ & $\mathrm{F}$ & Fark \\
\hline Okuryazar Değil & 1174.17 .71 & Gruplar & & & & \multirow{6}{*}{\multicolumn{2}{|c|}{$\begin{array}{cc}\text { 7.665*.000 } & \text { Okuryazar-Lise } \\
\text { Okuryazar-Üniversite } \\
\text { İlkokul-Lise } \\
\text { Illkokul-Üniversite }\end{array}$}} \\
\hline Okuryazar & 794.13 .87 & Aras1 & 16.849 & 5 & 3.370 & & \\
\hline İlkokul & 4984.30 .65 & & & & & & \\
\hline Ortaokul & 2904.35 .61 & Grup & 570.637 & 1298 & 3.440 & & \\
\hline Lise & 2394.49 .65 & & & & & & \\
\hline Üniversite & 814.56 .67 & Toplam & 587.486 & 1303 & & & \\
\hline
\end{tabular}

Tablo 11'deki varyans analizi sonucu, annenin eğitim durumu değişkeni açısından öğrencilerin metinlerin tümce anlambilimi açısından yapısına ilişkin görüşlerinin anlamlı şekilde farklılaştığını göstermektedir $[\mathrm{F}(5-1298)=7.665$; $\mathrm{p}<.05]$. Scheffe testi farklılaşmanın okuryazar olmayan annelerin çocukları (4.17) ile lise (4.49) ve üniversite (4.56) mezunu annelerin çocukları arasında gerçekleştiğini göstermektedir. Okuryazar olmayanların çocukları "sık s1k" düzeyinde görüş belirtirken, lise ve üniversite mezunu olan annelerin çocukları "her zaman" düzeyinde görüş belirtmişlerdir. Bu durum da lise ve üniversite mezunu olan annelerin çocuklarının ders kitaplarındaki metinlerin tümce anlambilimi yapısına ilişkin görüşlerinin daha olumlu olduğunu göstermektedir. Bir başka ifade ile eğitim durumu yükseldikçe metinlerin alımlanma seviyelerinin yükseldiği dile getirilebilir. Yine Scheffe testi anne eğitim durumu 
değişkeni açısından okuryazar olan (4.13) ile lise (4.49) ve üniversite (4.56) mezunları arasında ortaya çıktığını göstermektedir. Bu durum da lise ve üniversite mezunu olan annelerin çocuklarının Türkçe ders kitaplarındaki metinlerin tümce anlambilimi açısından yapısına ilişkin görüşlerinin okuryazar olan annelerin çocuklarına göre daha olumlu olduğunu göstermektedir. Yine Scheffe testi anlamlı farklılaşmanın ilkokul mezunları (4.30) ile lise (4.49) ve üniversite (4.56) mezunu annelerin çocukları arasında ortaya çıktığını göstermektedir. Bu durum da lise ve üniversite mezunu olan annelerin çocuklarının Türkçe ders kitaplarındaki metinlerin tümce anlambilimi açısından yapısı aşamasına ilişkin görüşlerinin okuryazar olan annelerin çocuklarına göre daha olumlu olduğunu göstermektedir. Tablo değerlendirildiğinde üç yönden anlamlı farklılaşmanın olduğu görülmektedir. Sonuç olarak annenin eğitim durumu arttıkça metinlerin tümce anlambilimi yapısına ilişkin görüşlerin olumlu yönde belirginleştiği tespit edilmiştir.

Tablo 12

Baba Eğitim Düzeyine Göre Tümce Anlamı Becerilerine İlişkin Öğrenci Görüşlerine Ait Varyans Analizi Sonuçları

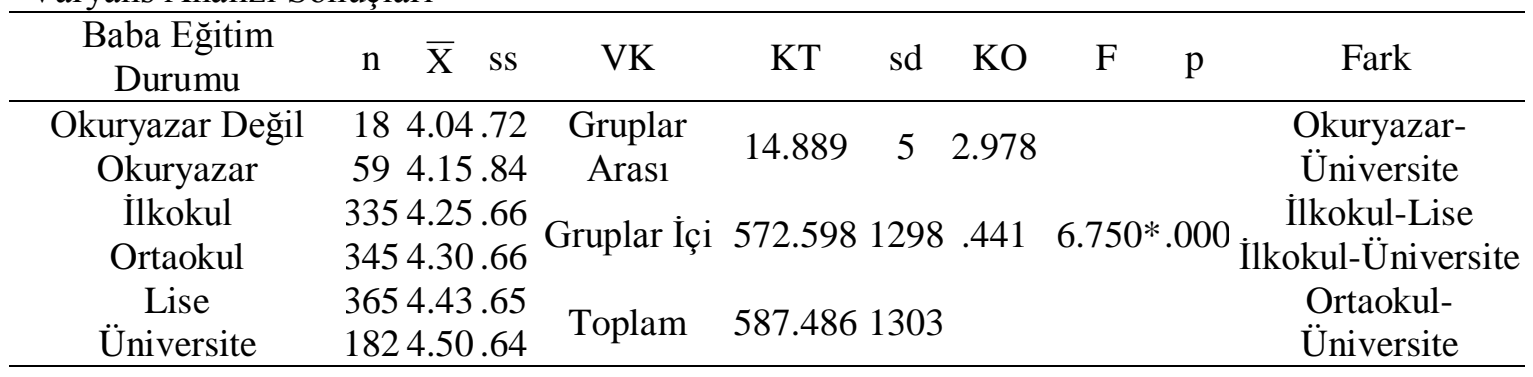

Tablo 12'de varyans analizi sonucu, babanın eğitim durumu değișkeni açısından metinlerin tümce anlambilimi yapısı aşamasına ilişkin öğrenci görüşlerinin anlamlı biçimde farklılaştığını göstermektedir $[\mathrm{F}(5-1298)=6.750 ; \mathrm{p}<.05]$. Scheffe testi farklılaşmanın baba eğitim durumu bakımından üniversite (4.50) ile okuryazar (4.15), ilkokul (4.25) ve ortaokul (4.30) mezunlarının çocukları arasında gerçekleştiğini göstermektedir. Bunlardan üniversite, ilkokul, ortaokul mezunlarının çocukları "her zaman"; okuryazar olan babaların çocukları "sık s1k" düzeyinde görüş belirttikleri tespit edilmiştir. Yine Scheffe testi öğrencinin babasının eğitim durumu değişkeni açısından ilkokul mezunu (4.25) ile lise (4.43) ve ortaokul (4.30) düzeyleri arasında anlamlı bir farklılaşmanın olduğunu göstermektedir. Bu üç eğitim durumu düzeyi açısından da öğrencilerin "her zaman" düzeyinde görüş belirttikleri belirlenmiştir. Bu bulgular değerlendirildiğinde iki yönden anlamlı farklılaşmanın olduğu görülmektedir. Araştırma kapsamında babanın eğitim düzeyi arttıkça çocukların başarı durumlarının paralel bir şekilde arttığ1 söylenebilir.

\section{Sonuç, Tartışma ve Öneriler}

Sözcük anlambilimi açısından metinlerin yansıtması gereken özelliklerden biri sözcüklerin gerçek anlamlarının öğrenciler tarafindan alımlanabilmesidir. Dil eğitiminde öğrencilerin en kolay ve rahat şekilde edindikleri ve kullanım olarak içselleştirdikleri anlamsal özellik gerçek anlam olmakla birlikte, öğrencilerin zorluk çektikleri anlamsal özelliklerin başında gerçek anlamın dışında kullanıldığı sözcüklerin anlaşılmasıdır (Özyürek, 2009). Bu durum araştırma kapsamında elde edilen sonucu desteklemektedir. Bir diğer önemli metinsel özellik ise eş anlamlılık özelliği bakımından öğrencilerin algı düzeylerine uygun anlam ilişkilerinin bulunmasıdır. Eş anlamlılığa yönelik gerçekleştirilecek bir araştırmada dikkat edilmesi gereken üç önemli husus bağlam, lehçe ve ağız özelliklerini içeren coğrafya ile zamandır (Sarı, 2012). Dilin anlatım gücünü artırması bakımından bir dil dizgesi içerisinde eş anlamlı sözcüklerin çok olması ve bundan dolayı da öğrencilerin eş anlamlı sözcükleri yetkin bir şekilde kullanabilmeleri önemlidir (İşcan, 2011). Bu nedenle ders kitaplarına metin seçilirken söz 
dizimsel açıdan anlam belirleyenler arasındaki uyuma özen gösterilmelidir. Özellikle üst sınıflarda düşünce yazılarının seçiminde anlam belirleyenler ve ayırıcılar arasındaki uyuma dikkat edilmesi öğrencilerin metinleri rahatlıkla alımlayabilmelerini sağlayacaktır.

Diller bünyesinde barındırdıkları zıtlıklar ve benzerlikler ile kullanıcılarını aşan büyülü bir güç konumundadır (Baranoğlu, 2011). Dil kullanıcıları olarak ise duygularımızı daha iyi belirtmek için sözcüklerin karşıt anlamlarından yararlanırız (İşcan, 2011). Araştırmada karşıt anlamlılık özelliği gösteren sözcükleri içeren metinlerin özellikle 6 ve 7. sınıf ders kitaplarında tercih edilmesi, sözcükte anlam konularının bu sınıf düzeylerine yoğun olarak verilmesinden dolayı son derece önemlidir. Karşıt anlamlılık özelliğinin ikili, biçimsel, dereceli ve yön gösteren karşıtlıklar olmak üzere, her türünün metinlerin söz varlıklarında yeterince yer bulmaları anlam konularının öğretilmesinde faydalı olacaktır. Özellikle mevcut ders kitaplarının söz varlıklarında yetersiz düzeyde olduğu belirlenen dereceli ve yön gösteren karşıtlıklara daha fazla yer verilmelidir. İletişim aracı olarak dil; sabit olmayan, devingen, değişken ve toplumsal bir olgudur. Sosyal dilbilim açısından bağımlı ve bağımsız biçimbirimler kullanıldığı bağlam ve zamanla ilişkili olarak gösterilen boyutunda son derece değişkendir. Bu değişkenlik kaynaklı, gösterilen boyutunda eşsüremsel olarak çeşitli kavramlara karşllık gelebilir. Bu durum da gösterenin artsüremsel akış içerisinde çeşitli anlam alanlarını karşılayabilecek şekle dönüşmesini sağlar. Dilbilimsel bu dönüşüm gösterge açısından çok anlamlılık özelliğinin kazanılmasına neden olmaktadır. Bu noktada alımlayıcı konumundaki öğrencilerin sözcüklerin kavram alanlarındaki çeşitliliğin farkında olmaları ve bu anlam birimcik demetlerine ulaşabilmeleri ana dili eğitimi açısından önemlidir. Her dildeki sözcüklerin büyük bir kısmının zamanla sosyal ve toplumsal değişikliklere bağlı olarak çok anlamlı bir yapıya büründükleri bilinmektedir (İşcan, 2011). Dil eğitiminde bireyin bir dilin söz varlığını oluşturan sözcüklerin anlamsal özelliklerini yeterince alımlayabilmeleri, tümel dil birimlerini düşünsel edimlerle tikelleştirebilmeleri açısından önemlidir.

Ana dili eğitiminde özellikle yazınsal değeri yüksek olan metinler kullanılmalıdır. Yazınsal metinlerin metin içi göstergelerinin çok çeşitli ve zengin yan anlam özellikleri göstermeleri, alımlayıcının zihinsel olarak üst metin oluşturması açısından önemlidir. Gerek yazında gerekse günlük dilde sözcüklerin farklı kullanımlara, sebeplere ve anlam olaylarına bağlı şekilde yeni kavramları karşılar duruma gelerek kazandıkları anlamlar yan anlam olarak adlandırılır (Demirtaş, 2012). Aslında çekirdek anlamı karşılayan ilk anlam, temel anlam, gerçek anlam gibi adlandırmalar çok anlamlı bağımsız biçimbirimlere özgü olup yan anlamları kesinlemede kullanılır (İşcan, 2011). Araştırma öğrencilerin göstergenin yan anlam özellikleri açısından belirli bir düzeyde farkındalığa sahip olduklarını gösterse de diğer maddelerle karşılaştırıldığında alımlama düzeylerinin düşük olduğunu kesinlemektedir. Buna karşılık gerçekleştirilecek eleştirel okuma yöntemleri ile göstergelerin bağlamsal anlamlarında meydana gelen değişikliklerin farkına varma düzeyleri artırılabilir. Metinlerin yan anlam, ad aktarmaları, deyim aktarmaları açısından zengin olması Türkçe derslerinin önemli bir bileşeni olan yazın öğretimi açısından önemlidir.

Anlambiliminin içerisinde bir tür alt disiplin olarak değerlendirilebilecek olan ad bilimi, çevremizdeki soyut ve somut bütün varlıkların adını çalışma nesnesi edinir (Sarıtaş, 2009). Ad bilimi bir yandan sözcük ile kavram arasındaki nedensiz ilişkiye ele almakta, bir yandan da özel adların kökenini, miktarını ve kültürel konumunu incelemektedir. Özel adlar, tek bir göndergeye karşılık gelen göstergelerdir. Buna karşıllı özel adlar metnin anlamının yapılandırılmasında son derece önemlidir. Çünkü özel adlar hem dil bilgisel açıdan o dilin özelliklerini yansıtır hem de alımlama esnasında okura toplumsal, kültürel, dinsel, ekonomik, coğrafi, tarihsel vb. özellikler hakkında bilgi verir. Doğal olarak okuma sürecinde son derece etkilidir. Ayrıca öğrencilerin adları ve adılları öğrenebilecekleri en uygun araç Türkçe ders kitapları olduğundan, bu kitaplardaki adların ve adılların doğru kullanımı ve 'çocuğa görelik' ilkesine uygunluğu büyük önem taşımaktadır (Kurtoğlu ve Uçar, 2011). Özellikle özel adların karşıladıkları kavramlarla olan tek yönlü ilişkilerinin göz ardı edilmeden okuma gerçekleştirilmelidir. Yazın metinlerinde kullanılan özel adlar asla tesadüflere bırakılmamalı ve karşıladığı kavram ile anlamları arasındaki bağ alımlamaya katkıda bulunmalıdır. Dil ile iletişim bilgilerine sahip olmak, o dilin 
kök bağlam ve art bağlam bilgilerine, bunlara uygun şekilde dil ve iletişim simgelerine, simge dizgelerine ve değişkenlerine hâkim olmak anlamına gelmektedir (Çakır, 2004). Buna göre bir kavramın anlamının sadece içerisinde bulunduğu bağlam içerisinde kendisini kesinleyebileceğini, öğrencilerin de bağlama bağlı olarak bir durum ya da kavrama farklı anlamlar yükleyebileceğini söyleyebiliriz (Sağlam ve diğerleri, 2012). Buradan hareketle yazılı dilde, bir sözcüğün gerçek anlam alanını metnin bağlamında oluşturduğu söylenebilir. $\mathrm{Bu}$ noktada metin okunurken okur metnin bağlamını asla göz ardı etmemeli ve anlamın gerçekleşme sürecini bu doğrultuda yönlendirmelidir. Özellikle okuma esnasında anlamı bilinmeyen sözcüklerin anlamlarının tahmin edilmesi, dil eğitimi sürecinde sık sık başvurulan yöntemlerdendir.

Dilbilim alanında gerçekleştirilen çalışmalar sözcüklerin eski dilcilerin dediği gibi kavramların içine yerleştirildiği kalıplar olmadığı, aksine birbiri ile sıkı ilişkiler içerisinde olan dil dizgesi içerisinde, dil birliği içerisindeki üyeler için, genellikle ortak sayılabilecek, birtakım tasavvurların, kavramların ortak bireşiminden oluştuğunu göstermektedir (Aksan, 1989). Bu durum bir doğal dilin söz varlığını oluşturan bağımlı ve bağımsız biçimbirimlerin kavram alanları sahip oldukları anlam birimcik demetlerinin benzerlikleri ile yakınlaşırken; anlam birimcik demetlerinin farklılıkları ile ayrışmakta, bazı göstergeler açısından da uzaklaşarak kopmakta olduğunu göstermektedir. Eşsüremsel açıdan alımlayıcının göstergenin ilişkili olduğu göndergeye yönelik duygu değeri ve sözcelem durumundaki kullanımı kavram alanlarının oluşmasında etkili olmaktadır. Ayrıca okuma esnasında metnin okuma izotopisinin ne yönde oluşacağı, sözcelem öznesinin metne etkisinin ne boyutta sınırlı kalacağı, metnin okur kitlesine uygunluk düzeyi gibi özellikler sözcelem durumunda metnin derin yapısında yer alacak kavram alanlarının seçimi ile yakından ilişkilidir. Ayrıca kavram alanlarına yönelik gerçekleştirilecek betimsel nitelikte bir çözümleme, aynı zamanda o dilin kullanıcı kesitine yönelik gerçekleştirilen düşünceye ve yaşam tarzına yönelik bir belirleyimdir. Sadece bir alana ait dil malzemesini ortaya koymakla kalmayan kavram alanlarına yönelik çalışmalar; bir dili kullananların düşünce ve yaşam tarzlarının, kimi zaman da psikolojik yapılanmalarının tespitine firsat verir (Çetin, 2009). Ayrıca Türkçe eğitiminde gerçekleştirilecek tematik öğrenme açısından seçilen kavram alanlarının da temalara paralellik göstermesi uygun olacaktır. Metinler seçilirken alımlayıcı kitlesinin özelliklerinin, sosyoekonomik farklılıkların, temalara uygunluğun ve çocuğa görelik ilkesinin dikkate alınması kavram alanlarına ulaşma düzeyini artıracaktır.

Bir sözcük anlamını bağlam içerisinde kesinler. Bunda sözceyi üreten sözcelem öznesinin, sözcelem durumunun, okunma zamanının ve alımlayıcının göstergeye ilişkin duygu değerinin etkisi vardır. Özellikle duygu değeri, göstergenin anlam birimciklerinin hangilerinin gerçekleşeceğini ve gösterilen boyutunun alımlayıcı açısından nasıl şekilleneceğini belirler. Özellikle bir şiiri etkileyici, duygulandırıcı ve doğal olarak da kalıcı kılan etkenlerin başında, kuşkusuz şairin dili kullanmadaki, duygu ve düşüncelerini, zihinde beliren özgün imgeleri okuyan veya dinleyene aktarmadaki başarısı gelir (Keklik, 2013). Duygu değeri özellikle şiir dili için geçerli olup anlamsal açıdan alımlamayı duygusal bir çerçeveye oturtur. Çünkü şiir sessel, görsel, söz dizimsel, biçimsel, anlamsal birçok katmanın iç içe, üst üste, yan yana ya da sarmal biçimde bulunduğu bir anlatım biçimi olup anlam bütün katmanların birlikte algılanmasıyla şekillenir (Korkut, 1996). Hem düz yazı örneklerinde hem de şiirlerde öğrencilerin yaş dönemi özelliklerinin, sosyoekonomik yapılarının, ilgilerinin ve çağın gerektirdiklerinin dikkate alınması; metin içerisinde bu doğrultuda özel sözcüklerin yerleştirilmesi metnin anlaşılmasını kolaylaştıracaktır. Metin seçiminin ve yazımının öğrenci merkezli gerçekleştirilmesi bu oranın daha da artmasını sağlayacaktır. Bu nedenle ana dili eğitiminde kullanılan metinlere, bağlamsal unsurlarının etkililik derecelerinin dikkate alınarak ders kitaplarında yer verilmesi son derece önemlidir.

Türkçede doğadaki nesneleri veya varlıkları karşılayan sözcüklerin insan için kullanılması ya da insan organ adlarının, vücut parçalarının doğaya uygulanması, somutlaştırmalar ve kişileştirmeler sonucu birer söz sanatı olarak birçok aktarma ortaya çıkmıştır (Nalbant, 2006). Doğal olarak bu tür söz sanatları metinlerin yazınsal çerçevede 
değerlendirilmesini sağlayabileceği gibi, okuma hazzını da artıracak ve okuma disiplinin ögrencilere kazandırılmasında etkili olacaktır. Bir yazınsal metinde aktarmaları bulabilmek öğreniciler açısından oldukça zor olmakla beraber yazınsal okuma becerilerini de gerekli kılmaktadır. Unutulmamalıdır ki söylediği şeyi kasteden bir yazınsal metin olmayacağı gibi bu tür metinler anlatıma canlılık ve hareket kazandıran aktarmalar ile doludur (Yaylagül, 2005). Bir yazınsal metin içerisindeki ad ve deyim aktarmalarına yönelmek aynı zamanda yazınsal türden bir alımlamanın daha etkin bir şekilde gerçekleştirilmesini sağlar. Ortaokul açısından öğrencilerin elde etmeleri gereken bir diğer dilsel beceri metin içerisindeki benzetme sanatlarının farkına varabilmeleridir. Genelde söz sanatları özelde de benzetmenin yoğun olması ve kullanılması bir dilin kullanışlığının yanı sıra yazınsallığına da işaret etmektedir (Aydın, 2006). Benzetme sanatı genel olarak insan ile topluma ait unsurların tabiata ait unsurlarla ilişkilendirilmesine dayanır ve bu ilişkide insan ile topluma ait unsurlar çoğunlukla büyüklük, küçüklük, iyilik, kötülük, güçlülük, zayıflık ve şekil ile ilgili olarak benzeyen işlevini üstlenir (Eren, 2009). Bu yolla öğrenciler varlıklar arasındaki ortak ve farklı yönleri fark edecek, diş dünyayı daha yakından tanıyabileceklerdir. $\mathrm{Bu}$ bağlamda öğrencilerin benzetme sanatı örneklerine rahat bir şekilde ulaşabilmeleri, bu söz sanatı örneklerini tespit edebilmeleri ana dili eğitimi açısında önemlidir. Yazınsal metinlerde soyut kavramları temsil yoluyla, hayalleri somut biçimde ve unsurları karşı1ıklı olarak birbirini açıklayacak şekilde ilişkilendirme esasına dayalı olan abartma, alımlamayı etkileyici bir düzleme çeken bir söz sanatıdır (Karaköse, 2010). Çocukların hayal dünyalarını harekete geçirmesi, çocuğun bilişsel yapısına ve dünya algısına paralellik göstermesi açısından abartmaya yönelik örneklerin Türkçe eğitiminde kullanılan metinlerde yeterli oranda yer alması gerekmektedir.

İnsan, ana dilini belirli bir süreçte, toplumun o dili kullanım şekliyle ve doğal şartlar içerisinde öğrenir ve bu doğal süreç içerisinde söz varlığını oluşturur. Bu bağlamda herhangi bir sözcüğün ne anlama geldiği toplumun kullanım şekliyle istikrarlı hale gelmektedir (Coşkun, 2008: 34). Bu süreçte sözcüklerin anlamları artsüremsel açıdan sürekli değişkenlik gösterir ve bir noktada anlam değişmelerine zemin oluşturur. Anlam değişmelerinden olan anlam daralması ise sözcüğün eskiden karşıladığı kavramın sadece bir bölümünü, bir kesitini anlatabilir duruma gelecek şekilde gösterilen boyutunda gerçekleşen değişmedir (Sav, 2003). Artzamanlı dilbilimin ve art zamanlı anlambiliminin çalışma alanında bulunan anlam değişmeleri bir dilin doğal devingen yapısının en önemli göstergeleridir. Buna karşılık ilgili anlam değişmelerinin hangi boyutta bulunduğu, iletişim ortamında nasıl bir işlev üstlendiği, sözcenin alımlanma boyutunda nasıl çözümlendiği eşsüremsel olarak yapısı ile yakından ilişkilidir. Araştırmada öğrencilerin anlam değişikliklerinin farkına varabilme noktasında sıkıntı yaşadıkları tespit edilmiştir. Bir dilsel göstergedeki anlam genişlemesini veya genelleşmesini kökanlamı temel çıkış noktası olarak değerlendirip sistematik şekilde gerçekleştirilecek artzamanlı bir inceleme ile tespit edebilmek mümkündür (Sav, 2003). Bu noktada eşsüremsel bakış açısı, öğrencilerin ilgili dilsel göstergenin çok anlamlılığını kapsayan anlamsal çerçeveyi ve dilin sınırlı sayıdaki bağımlı ve bağımsız biçimbirimlerle sınırsız sayıda ifade olanağı sunabilme özelliğini kavramalarını ve edinmelerini sağlayacaktır. Canlı bir varlık olduğundan sürekli bir gelişme gösteren dildeki değişmenin hızı yavaştır ve dilin bünyesinde meydana gelen değişmeler ancak belli bir zaman diliminden sonra netleşmektedir (Üşenmez, 2008). Uzun zaman dilimlerinde gerçekleşen anlam değişiklerinden biri de anlam iyileşmesidir. Dil dizgesi içerisindeki bağımsız biçimbirimlerin eskisine göre daha iyi bir anlamı karşılar duruma gelmesine anlam iyileşmesi, anlam güzelleşmesi veya anlam soylulaşması denir (Sav, 2003). Öğrencilerin anlam iyileşmesinin farkına varabilme özelliklerine yeterli düzeyde ulaştıklarını, ancak diğer maddelerle karşılaştırıldığında ise başarı düzeylerinin düşük kaldığını söyleyebiliriz. Anlam kötülenmesini kısaca, bir sözcügün eskisine göre daha olumsuz ve hoş olmayan kötü bir anlam taşır duruma gelmesi şeklinde tanımlayabiliriz (Atay, 2010). Araştırma; öğrencilerin yakın ilişkili olduğu anlam iyileşmesine karşıt, anlam kötüleşmesine daha yeterli düzeyde kavrayabildiklerini göstermektedir. Nüfus hareketleri, göçler, toplumu derinden etkileyen savaşlar, devrimler, ticari ilişkilerin gelişmesi, yeni siyasi gelişmeler ve teknik alandaki gelişmeler dilsel göstergelerde anlam kaymasına yol açabilir (Sav, 2003). Anlam kayması düzdeğişmece, eğretileme, 
kapsamlayış gibi yollarla ya da aynı söz dizgesi içerisindeki sözcüklerin farklı bir anlama geçişi ile de gerçekleşebilir. Kısacası bir sözcüğün zaman içerisinde kendi anlamından uzaklaşarak farklı bir anlama geçmesidir. Genel olarak değerlendirildiğinde ise anlam daralması, anlam genişlemesi, anlam iyileşmesi, anlam kötüleşmesi ve anlam kayması gibi anlam değişimlerine ögrencilerin ulaşma düzeylerinin diğer maddelerdeki oranlara göre daha düşük olduğu tespit edilmiştir.

Ölçünlü dil, lehçe, topluluk dili ve üye olunan topluluğa göre kullanılan jargon veya argo bireysel dil için kaynak oluşturmaktadır (Önem, 2011). Ana dili eğitimi her ne kadar ölçünlü dil örnekleri ile öğrenciyi genel olarak tanıştırmaya çalışsa da çocuğa hayat tecrübesi kazandırması açısından farkındalık uyandırması gerekmektedir. Çok hassas olan bu konuda öğrenci; seviyeli metinlerle tanıştırılmalı, ancak tamamen günlük dilden yoksun da bırakılmamalıdır. Argo dilin doğal bir parçasıdır, çünkü insan sosyal ve duygusal bir varlıktır ve bu unsurları doğal olarak da dil dizgesine yansitır. Dilin kendi bünyesinde iyi, güzel, çirkin vb. pek çok konuyu barındıran yapılar ve kavramlar ne kadar çok bulunursa dil o kadar işlek durumdadır (Şenel, 2009). Ana dili eğitiminin önemli işlevlerinden birinin de canlı dili yansıtmak olduğu düşünüldüğünde yapılması gereken argoyu ortadan kaldırmaya çalışmak yerine abartmadan, aşırı uçlara yönelmeden farkındalık oluşturmak olmalıdır. Türkçe mecazlı anlatım örnekleri bakımından da son derece zengin bir dil olup bu da ana dilimizin anlatım yapısı bakımından bu türden söz varlığı unsurlarının öğrenciye edindirilmesini gerektirmektedir. Bir dildeki mecazların çokluğu, aynı zamanda o dilin çeşitli bakımlardan gelişmiş olduğunu göstergesidir (Alkayış, 2004). Metinlerin mecaz anlam bakımından zengin örnekler göstermesi, öğrencilerin söz varlıklarının gelişmesi ve dili etkili kullanmaları açısından faydalı olabilir.

Bir fikri, duygu veya düşünceyi, bir oluş ve kılışı yargı şeklinde aktaran sözcük grubuna tümce denir (Korkmaz, 2007). Yargının gerçekleştiğini anlatan; yapma, yapılma ya da olma bildiren tümceler olumlu tümce olarak değerlendirilirken, bu türden tümceler, bazen yapıca olumsuzken anlamca olumlu olabilir (Biray, 2007). Öğrencilerin metinlerdeki olumlu tümceleri fark edebilmeleri, diğer tümcelerdeki anlamsal yapılarla karşılaştırabilmeleri gerekmektedir. Araştırma, ders kitaplarında yeterli miktarda olumlu tümceye yer verildiğini göstermektedir. Ayrıca yaşamdaki zıtlıklar dil içerisinde duygular, düşünceler ve hayaller ifade edilirken olumlu ve olumsuz kavramlar dil içerisindeki çeşitli yapılarla karşılanır (İlhan, 2005). Bu bağlamda öğrencilerin bu olumlu ve olumsuz tümceleri fark edebilme düzeyleri, bir anlamda yaşamdaki zıtlıklara ulaşabilme düzeyleri hakkında birtakım göstergeler sunacaktır. Türkçe ders kitaplarındaki metinlerde yer alan olumsuz tümcelerin anlam konularının öğretilmesi açısından kolaylıkla tespit edilebilmesi, alg1 düzeylerine uygun olması gerekmektedir. Anlamlarına göre tümceler ele alınırken yapısal olumsuzluk ile anlamsal olumsuzluk kavramlarını birbirinden ayırmak gerekir. Anlamlarına göre tümceleri sınıflandırırken tümcenin hem yapısına hem de anlamına dikkat ettiğimizden olumsuz tümce başlığı altında değerlendirdiğimiz tümcelerin hepsi anlamca olumsuz olmayabilir yani yapıca olumsuz olan bir tümce anlamca olumlu da olabilir (Demirel, 2005). Araştırmaya katılan öğrencilerin metin içerisindeki olumsuz tümceleri yeterli düzeyde fark edebildikleri belirlenmiştir. Anlamca olumlu ya da olumsuz bir nitelikte olabilecek soru tümceleri, soru sorma yolu ile bilgi almayı hedeflemektedir ve tümceye soru anlamı kazandırmak için soru ön adları, soru adılları, soru belirteçleri, soru ilgeçleri, soru eki kullanılabilir (Biray, 2007). Araştırmada TÜDÖP ile ilişkili bir şekilde alımlama esnasında öğrencilerin soru tümcelerini doğru bir şekilde fark edebilmeleri, yorumlayabilmeleri, diğer tümceler ile olan anlamsal ve yapısal farklarını karşılaştırabilmeleri beklenmektedir. Ancak Türkçenin söz dizimsel açıdan yüksek orandaki hareketliliği ve ezgi ile soru tümceleriyle bilgi yapısı açısından çok yönlü olan ilişkiler sergilemesi, soru tümcelerinin tespitinde ve betimlenmesinde daha ayrıntılı bir yaklaşım sergilenmesini zorunlu kılmaktadır (Uzun, 1988). Yapılması gereken ise dilbiliminin verileri ışı̆̆ında, Türkçenin söz dizimini de dikkate alarak soru tümcelerindeki yapısal özelliklerin belirlenmesi ve ana dili öğretim programlarına yansitılmasidir.

Dil hem bir mesajı karşı tarafa aktaran bir iletişim aracı hem de duygularımızı ifade etme olanağı sunan bir tür sergileme aracıdır. Duygularımızı ve hissettiklerimizi en keskin ve 
kısa şekilde aktarmada ünlemler vazgeçilmez bir araçtır (Shakhin, 2013). Bunun yanı sıra şart kipi haricindeki durum kipleri için anlamca tamamlanmış bir yargı söz konusuyken, şart kipinin tek başına anlamca tamamlanmış bir yargı ifade edememesi onun birleşik tümcelerde değerlendirilmesini gerektirmektedir (İlhan, 2007). Bu durum birleşik tümcelerde şart ilişkisiyle kurulan yan tümce ile temel tümce arasındaki ilişkiyi belirleyebilmeyi gerektirmektedir. Öğrencilerin tümce anlamı bakımından tümcelerin şart ilişkisine rahatlıkla kavuşabilmeleri, hem rahatlıkla anlamsal yapıya hem de yapısal özelliklere ulaşabildiklerini göstermektedir. İstek kipi -(y)A, ölçünlü Türkçede kullanım alanı daralmış ve kullanımlarının çoğunda istek dışında dilek, olasılık, tahmin, çıkarım, öneri, nasihat gibi anlamları bildirmektedir (Demir ve Aslan, 2010). Araştırma kapsamında ise istek kipi ile çekimlenen bütün tümceler genel olarak bir başlık altında değerlendirilmiş ve öğrencilerin görüşleri de bu yönde alınmıştır. Türkçe ders kitaplarındaki metinlerin tümce anlambilimi açısından istek tümcelerinin örneklerini içermesi, bu örneklerin diğer tümce türleri gibi sanatsal değer taşımaları gerekmektedir. Bu türden tümceler metin içerisindeki kurgusal dünyaya ya da dil dişı gerçek dünyaya ait karakterlerin sözcelem durumlarındaki niyet yapılarına ulaşılmasını kolaylaştıracaktır. Emir kipi ise bildirişim ortamında vericinin alıcıdan bir şey yapmasını ya da yapmamasını isteyen kip olarak tanımlanmaktadır. Türkçe dil bilgisi çalışmalarında, emir kavramı, kipsel/kiplik bir değer olarak tasarlama kipleri içindeki emir kipi başlığında işlenmektedir (Karademir, 2012). Ayrıca eylemlerin emir biçimi, bir isteğin, arzunun emir şeklinde ifadesi olduğundan emir kipleri rahatça istek işlevine kayabilmekte ve bu istek işlevinden rica veya yalvarma gibi işlevler de ortaya çıkabilmektedir (Ercilasun, 2008). Buna karş1lık emir tümceleri, gerek yazın gerekse günlük konuşmalarda oldukça önemli yer kaplar. Ana dili eğitiminde ise ne yazık ki gerekli önem verilmez, hızlı geçiştirilir. Gereklilik kipinin ana işlevi de gerçekleştirilmesi tasarlanan bir işin gerekli olduğunu bildirirken, bunu emir biçiminde değil de daha çok içten gelen, konuşana bağlı bir gereklilik şeklinde ifade etmektedir (Korkmaz, 2003). Araştırmanın verileri "gereklilik tümcelerinin" ortaokul öğrencileri tarafından belirlenebildiklerini kesinlemektedir.

Dil; sadece bir dilin bir mesajı vericiden alıcıya aktarmaya yarayan bir araç değil, aynı zamanda bir tür gerçekleşim, bir tür edimdir. Bu işlevi ile sözcelem öznesi ile alımlayıcı arasında, özellikle konuşma dilinde, bir tür etkileşimdir. Özellikle konuşma dilinde alımlayıcı üzerinde bırakacağı etki, onun yönlendirilmesi, sözcelem öznesinden bağımsızlaşan sözcenin alımlayıcıya yansıması farklı etki boyutlarında veya kapsamında olabilir. Tam bu noktada edim bilim devreye girer ve sözcelem öznesinin niyetini tespit etmeye çalışır. Bunun için de bizlerin okur olarak metnin derinliklerinde yatan kavramsal ilişki ağlarına ulaşmamız, deneyim ve birikimlerimiz ışığında metni anlamamız gereklidir (Yetkiner, 2009). Bu nedenle Türkçe ders kitaplarındaki metinlerde yer alan konuşma örneklerini alımlamada öğrencilerin kendi bilgi ve tecrübelerini yansıtabilme düzeylerinin belirlenmesi hedeflenmiştir. İletişim doğal dil dizgesi üzerinden oldukça etkindir ve yönlendirilmeye açık bir düzlemde, çizgisel sırada gerçekleşir. Kodlanan iletiyi çözümleyen alımlayıcı, aslında sadece iletiyi değil aynı zamanda sözcelem öznesinin dilsel kodlara yüklediği duygusal, yönlendirme ve etkileme işlevi olan kodları da çözümler ve alımlar. Özellikle konuşma dilinde bürünsel yapının ve uzamın da etkisiyle sözce salt bir göstergeler boyutu olmaktan kurtulur ve derin yapıdan yüzeysel yapıya doğru, yani soyuttan somuta doğru kendisini gerçekleştirir. Dilin "çağrı işlevi" ile ilgili olan bu durum hem sözcelem durumuna hem de alımlama sürecine yön verir. Çağrı işlevi tümüyle alıcı kaynaklı bir işlev olup alıcıya gönderme yapar ve kısaca gönderici tarafindan söylenen ya da yazılan dilsel birimlerin yani metinlerin alıcıda uyandırdığı etkileri karşılamaktadır (Kılıç, 2009). Sağlıklı bir iletişim açısından sözcelem öznesinin sözceyi anlamsal ve yapısal açıdan tam olarak gerçekleştirmesi gerekmektedir. Aksi halde alıcı konumundaki alımlayıcı kodlanan bilgiyi tam olarak çözümleyemeyecek ve doğal olarak da bildirişimin kusurlu bir şekilde gerçekleşmesi ya da iletinin tam olarak anlaşılmaması söz konusu olacaktır.

Sonuç olarak metinlerde; eşanlamlılık özelliği, çok anlamlılık özelliği gösteren, yan anlamda kullanılan, sesteş özellik gösteren sözcüklerin, kavram alanlarının, duygusal anlamı olan sözcüklerin, aktarmaların, benzetme sanatlarının, metinlerde geçen özel adlar ile karşıladıkları kavramlar arasındaki anlam ilişkilerinin, bağlamsal anlam farklılıklarının, anlam 
daralmalarının, anlam genişlemelerinin, anlam iyileşmelerinin, anlam kötüleşmelerinin, anlam kaymasına uğramış sözcüklerin ve argo ifadelerin farkındalığının artırılmasına ilişkin çalışma kitaplarında daha fazla etkinliğe yer verilmesi yararlı olacaktır. Yine öğrencilerin gerçekleştirecekleri yazınsal okumalara yönelik seçilecek eserlerin bu anlam özelliklerini yansıtacak nitelikte olması gerekmektedir. Ayrıca sosyoekonomik düzey farklılıklarını dikkate alan metinlerin ders kitaplarında yer alması ya da bu türden bazı metinlerin ders kitaplarında ayrı bir bölümde ek olarak sunulması, kitap dağıtımlarında sosyoekonomik farkların da gözetilmesi sosyoekonomik düzey kaynaklı sorunların giderilmesinde yararlı olabilir.

\section{Kaynaklar}

Aksan, D. (1989). Kavram alanı-kelime ailesi ilişkileri ve Türk yazı dilinin eskiliği üzerine. TDAY - Belleten, 253-262.

Aksan, D. (2003). Her yönüyle dil ana çizgileriyle dilbilim (III. Cilt). Ankara: TDK Yayınları.

Aksan, D. (2004). Dilbilim ve Türkçe yazıları. İstanbul: Multilingual Yayınları.

Alkayış, M. F. (2004). Türkçeyi iyi bilmeyen ya da yeni öğrenen bireylerin mecazlar konusunda karşılaştıkları güçlükler. XIII. Ulusal Eğitim Bilimleri Kurultayı, İnönü Üniversitesi Eğitim Fakültesi, 6-9 Temmuz 2004, Malatya.

Atay, A. (2010). Anlam kötüleşmesine uğramış güzel bir kelime: don. The Journal of Academic Social Science Studies International Journal of Social Science, 3(1), 1-11.

Aydın, E. (2006). Eski Türk yazıtlarında benzetme ilgisiyle kurulmuş cümleler üzerine. Erciyes Üniversitesi Sosyal Bilimler Enstitüsü Dergisi, 21(2), 65-72.

Baranoğlu, Ş. (2011). Ad vermede zıtlık ve benzerlik. Turkish Studies International Periodical for The Languages, Literature and History of Turkish or Turkic,6(1).

Bayrav, S. (1998). Yapısal dilbilimi. İstanbul: Multilingual Yayınları.

Biray, N. (2007). Türkiye Türkçesi ile Kazak Türkçesindeki cümlelerin çeşitleri bakımından karşılaştırılması üzerine bir deneme. Dil Araştırmaları Dergisi, 1(1).

Cemiloğlu, M. (2009). İlköğretim okullarında Türkçe öğretimi. Bursa: Alfa Aktüel.

Chomsky, N. (2002). Dil ve zihin. A. Kocaman (Çev.). Ankara: Ayraç Yayınları.

Coşkun, S. (2008). Anlam değişmelerinin sebep olduğu anakronik bakış ve hadis yorumlarındaki yanıltıcılığı. EKEV Akademi Dergisi, 35 .

Coward, R. ve Ellis, J. (2008). Dil ve maddecilik,V. Kılıç (Çev.). İstanbul: Toroslu Kitaplığı.

Çakır, C. (2004). Anlamın bağlam açısından incelenmesi: kökanlambilim ve artanlambilim. Gazi Üniversitesi, Gazi Ĕgitim Fakültesi Dergisi, 24(3), 245-255.

Çetin, E. (2009). Orhon yazıtlarında 'itaat' kavramı. Turkish Studies International Periodical for The Languages, Literature and History of Turkish or Turkic, 4(8).

Demir, N. ve Aslan, S. (2010). S1klık kopyası örneği olarak istek kipi-(Y)A. Turkish Studies International Periodical for The Languages, Literature and History of Turkish or Turkic, 5(4).

Demirel, Ö. (2005). Yapıca olumlu anlamca olumsuz cümleler hakkında bir değerlendirme. İstanbul Üniversitesi Edebiyat Fakültesi Türk Dili ve Edebiyatı Dergisi, 33.

Demirtaş, A. (2012). Kutadgu Bilig'de 'yorı-' fiili üzerine. Turkish Studies International Periodical for The Languages, Literature and History of Turkish or Turkic, 7(4).

Ercilasun, A. B. (2008). La enklitiği ve Türkçede bir 'pekiştirme enklitiği teorisi. Dil Araştırmaları Dergisi, 2, 35-56.

Eren, A. (2009). Dîvânü Lugâti’t-Türk'ün manzum parçalarında insan ve toplum ile İlgili benzetmeler. Uluslar Arası Sosyal Araştırmalar Dergisi, The Journal of International Social Research, 2(9).

Erol, H. A. (2008). Eski Türkçeden Eski Anadolu Türkçesine anlam değişmeleri. Ankara: TDK Yayınları.

Güneş, F. (2007). Türkçe öğretimi ve zihinsel yapılandırma. Ankara: Nobel.

İlhan, N. (2005). Türkçede olumsuzluk. Karaman Dil Kültür ve Sanat Dergisi, T.C. Karaman Valiliği Yayınları, Ankara: TBBM Basımevi, 271-279. 
İlhan, N. (2007). Birleşik cümle kuruluşunda şart cümlesi ya da zarf grubu. İstanbul Kültür Üniversitesi Uluslararası Türk Dili Ve Edebiyatı Kongresi, 27-28 Ağustos 2007, İstanbul.

İşcan, A. (2011). Anlam bilgisi konularının öğretimi. Turkish Studies International Periodical for The Languages, Literature and History of Turkish or Turkic, 6(2).

Karademir, F. (2012). Türkiye Türkçesinde emir kip(lik)i üzerine. Turkish Studies International Periodical for The Languages, Literature and History of Turkish or Turkic, 7(4).

Karaköse, S. (2010). Divan şiiri sevgili tipindeki abartıların simgesel boyutuna birkaç örnek. Uluslararasi Sosyal Araştırmalar Dergisi [The Journal of İnternational Social Research], Klâsik Türk Edebiyatı Özel Sayısı-Prof. Dr. Turgut Karabey Armağanı, $3(15)$.

Keklik, M. (2013). Dilbilimsel açıdan şiir dili ve bu bağlamda Baki’nin gazellerinde alışılmamış bağdaştırmalar duygu değeri ve uzak çağrışımlar. Turkish Studies International Periodical for The Languages, Literature and History of Turkish or Turkic, 8(9).

Kılıç, V. (2009). Anlambilime giriş temel kavramlar. İstanbul: Papatya Yayınları.

Korkmaz, Z. (2003). Türkiye Türkçesi grameri (şekil bilgisi). Ankara: TDK Yayınları.

Korkmaz, Z. (2007). Gramer terimleri sözlüğ̈̈. Ankara: TDK Yayınları.

Korkut, E. (1996). Şiirde duygu değeri ve "aşk". Hacettepe Üniversitesi Eğitim Fakültesi Dergisi, 12, 31-35.

Kurtoğlu, Ö. ve Uçar, A. (2011). İlköğretim Türkçe ders kitaplarında yer alan sözvarlığının derlem temelli incelenmesi; E. Yılmaz, M. Gedizli, E. Özcan, Y. Koçmar (Yay. Haz.). Türkçenin Eğitimi-Öğretimi Üzerine Çallşmalar içinde (93-102), Ankara: Pegem Akademi.

Marshall, J. (1994). Anadili ve yazın ögretimi, C. Külebi (Çev.). İstanbul: Çağdaş Yayınları.

Nalbant, M. V. (2006). Buldan Türkülerinde metaforlu ve metonomili (deyim aktarmalı ve ad aktarmal1) sözcükler. Buldan Sempozyum, Kasım, 23-24.

Nuhoğlu, M. M. (2007). Türkçe öğretimi etkinlikleri. Ankara: Nobel.

Önem, E. (2011). Bireysel dil kullanımını etkileyen etkenler. Dil Dergisi, (Nisan-MayısHaziran), 152.

Özyürek, R. (2009). Türk devlet ve topluluklarından Türkiye üniversitelerine gelen Türk soylu yabanc1 uyruklu öğrencilerin Türkçe öğrenimlerinde karşılaştıkları sorunlar. Turkish Studies International Periodical for The Languages, Literature and History of Turkish or Turkic, 4(3).

Sağlam, Y., Kanadlı, S. ve Uşak, M. (2012). Bağlamın öğrencilerin kavram imajı üzerine etkisi. Türk Fen Ë̆itimi Dergisi, (4).

Sarı, M. (2012). Türk dilinde eş anlamlılık ve "sayru-sökel" sözleri. Turkish Studies International Periodical for The Languages, Literature and History of Turkish or Turkic, 7(3).

Sarıtaş, S. (2009). Balıkesir Üniversitesi öğrencilerinin günümüzdeki adlar ve ad verme hakkındaki görüşleri. Balıkesir Üniversitesi Sosyal Bilimler Enstitüsü Dergisi, 12(21), 422-433.

Sav, B. (2003). Anlam değişmeleri üzerine artzamanlı bir inceleme. G.Ü. Gazi Ĕgitim Fakültesi Dergisi, 23(1), 147-166.

Shakhin, Z. (2013). Türkçe ve Rusça ünlemlerin çeviri sorunları. İdil, 2(6).

Şenel, M. (2009). Küfür etmenin lanet ve beddua okumanın çağdaş yolu: şarkı ve türküler. Turkish Studies International Periodical for The Languages, Literature and History of Turkish or Turkic, 4(8).

Uzun, N. E. (1988). Türkçenin öğretimi için soru tümcesi türleri üzerine bir sınıflama denemesi. Dil Dergisi.

Üşenmez, A. (2008). Tün sözü üzerine. Turkish Studies International Periodical for The Languages, Literature And History of Turkish or Turkic, 3(1).

Vardar, B. (2002). Açıklamalı dilbilim terimler sözlüğ̈̈. İstanbul: Multilingual.

Yalçın, A. (2002). Türkçe öğretim yöntemleri; yeni yaklaşımlar. Ankara: Akçağ Yayıncılık. 
Yaylagül, Ö. (2005). Dîvânü Lûgâti't-Türk’teki ad aktarmalı (metonymic) yapılar. Modern Türklük Araştırmaları Dergisi, 2(4).

Yetkiner, N. K. (2009). Çeviribilim edimbilim ilişkisi üzerine. İzmir: İzmir Ekonomi Üniversitesi Yayınları.

Yıldız, C. (2003). Ana dili öğretiminde çağdaş yaklaşımlar ve Türkçe öğretimi. Ankara: Pegem A Yayıncilik.

\section{Extended Abstract \\ Introduction}

Within the first step of the language training process the problem to be solved with the help of different questions, the information to be reached and rules or the characteristics to be emerged is presented to the student. Within the second step reaching new synthesis is aimed systemizing disconnected items by using forming information. Then in the third step configuring the new information gained with the formerly found ones and using them in the latest fields is a matter fact. At this point a good course book should include the texts that provide the application of these three steps. Because the texts used in mother language education, must be interesting, easy to understand and suitable for the level of the student. They must include a concrete style, have artistic value, fit for the purpose, and must have both a rich and a suitable vocabulary.

\section{Method}

The general purpose of this research is to determine the views of the students regarding the texts of 6, 7 and 8 grade Turkish course books in terms of lexical semantics and syntax. This study, which was carried out in quantitative pattern, was performed in scanning type. The universe of the research consists of the secondary schools in Malatya city centre.

\section{Sample/Study Group}

Within the sampling process stratified sampling, which is one of the random sampling methods, was used. The sampling was applied to 1.370 (95\%) students among 1.443 students, from 15 different secondary schools that are chosen by three from every education zone, each one belonging to low, medium and good socio-economic levels. Within the scope of the research one class from 6, 7 and 8 grade were included to the sampling; 66 scales were not evaluated for some reasons such as coding more than one choice, not marking the items and the missing parts of the personal information. As a result, 1.304 scales were evaluated the current status was attempted to be determined through descriptive scanning method.

\section{Data Gathering and the Analyze of the Data}

As data gathering tool a 31 item five likert type scale was developed. From the point of view of the field the draft scale developed was presented to 5 Turkish teachers who work in the city centre of Malatya province and the academic members of the Turkish Education and Educational Sciences departments; and some arrangements were made on the items. KMO value .94 , the results of Bartlett Test 4337,988 were found significant at the level of .05 indicate that the items could be applied factor analysis. It was seen that the factor loadings change between .32 and .69, Cronbach Alpha reliability coefficient of the first 20 items were .89 , the latter 11 items were .89, and Cronbach Alpha reliability coefficient of the scale as a whole was .93 . Sperman_Brown reliability coefficient was .87 and Guttmann split half coefficient was .87 . According to these results it can be said that the scale was reliable. The researcher went to the schools chosen and applied the scale to the students. Within the analysis of the data percent and frequency techniques, dependent group t test and variance analysis; and in the variance analysis scheffe test was used for determining the source of the significant difference.

\section{Findings}

The students were asked 20 items regarding the verbal meaning structures of the course books concerning how the fundamental features of the texts must be reflected in terms of lexical 
semantics are received by the students. It was interesting to see that the students expressed opinions at the lower level regarding the determination the changes of the meanings that require diachronic point of view and reflect to the universality of the language system within the indicated parts of the linguistic indicators. The total arithmetic average of the students' views regarding the structures of lexical semantics of the texts were at the level of "often" (3.97). It was determined that the views regarding lexical semantics differ according to the gender variable [t(1302) $=-5,209 ; \mathrm{p}<.05]$. This situation indicates that female students found the texts more positive when compared to the male students. It is revealed that the students' views regarding the level of lexical semantics structures of the texts differ significantly in terms of grade variable $[\mathrm{F}(2-1301)=22.811 ; \mathrm{p}<.05]$. As the level grade increase they consider the texts more inadequate in terms of lexical semantics. In terms of socioeconomic structure variable, it was seen that the views of the students, regarding the lexical semantics structures of the texts in Turkish course books, differ significantly $[\mathrm{F}(2-1301)=5,662 ; \mathrm{p}<.05]$. It can be said that comprehensibility levels regarding lexical semantics structures of the texts increase as long as the socioeconomic structure level increases. The views of the students differ significantly in terms of the education status of the mother variable $[\mathrm{F}(5-1298)=5.681 ; \mathrm{p}<.05]$. It can be said that the receiving levels of the texts increase as long as the education level of the mother increases. It was seen that the views of the students differ significantly in terms of father education status $[\mathrm{F}(5-1298)=6.228 ; \mathrm{p}<.05]$. In terms of education status it can be said that the children of the fathers graduated from university evaluate the texts in the course books more positively in terms of lexical semantics.

The participants expressed opinions; positive (4.57), negative (4.44), question (4.48), exclamation (4.49), conditional (4.26), optative (4.30), imperative (4.27), determining necessitative sentences (4.20); the intend and the attitude of the speaker (4.18), the methods of effective speaking (4.31), realizing clear, adequate and correct sentences (4.24), regarding linguistics skills at the level of "always". The total arithmetic average of the texts regarding syntax structures were at the level of "always" (4.34). This situation indicates that the students found the texts more positive in terms of syntax when compared to the lexical semantics. It was determined that it differs significantly in terms of gender variable [t(1302)=-6,976; $\mathrm{p}<.05]$. The arithmetic average of the groups participated in the research was determined as (4.48) in females and (4.22) in male students. It was seen that it differs significantly according to the grade level variable $[\mathrm{F}(2-1301)=14.624 ; \mathrm{p}<.05]$. This situation indicates that the linguistic features of the students regarding syntax remained at the low level as long as the grade level increases. It was seen that the views of the students differ significantly in terms of socioeconomic structure variable $[\mathrm{F}(2-1301)=8.345 ; \mathrm{p}<.05]$. This finding obtained indicates that the students from higher socioeconomic level found the texts more positive when compared to the ones from low socioeconomic level. It was seen that the views of the students differ significantly in terms of the education status of the mother variable $[F(5-1298)=7.665 ; p<.05]$. This situation indicates that the views of the children, whose mothers graduated from high school and university, were more positive regarding syntax of the texts in the course books. It was seen that the views of the students regarding syntax of the texts differ significantly in terms of father education status $[\mathrm{F}(5-1298)=6.750 ; \mathrm{p}<.05]$. Within the scope of the research it can be said that the success of the children increases as long as the education level of the father increases as well.

\section{Result and Recommendations}

While the texts that will take place in the course books are being chosen the harmony among the semantic markers must be paid attention in terms of syntactic issues; and the texts, in which incompatibility takes place in terms of semantic markers in its surface structure, must not be preferred. Instead of using the words that show synonymy in the same statement, it would be better to prefer the texts in which different statements are used. Especially, while choosing the texts of thoughts the way of using the synonymous words must be paid attention. Especially preferring the texts that include the antonymous words in the 6 and 7 grade course books is more important than giving the lexical meaning subjects at these grades. Within the vocabulary 
of the current course books, texts that include the graded antonyms that give direction and determined to be at the inadequate level must be preferred. The indicators that reflect heterographic features must be included within the texts of the $6^{\text {th }}$ grade and within the textual frame this meaning relationship must be embodied with different usages and awareness must be created in students with the help of activities. In terms of hyponymy relation these kinds of usages must be included both in course books and workbooks. Since conceptual field would determine the reading isotopy during the receiving of a text, it is important to embody the conceptual fields in which condensations occur in the texts used in mother language education. In terms of metonym including adequate number of examples in the texts, would ease up the acquirement of the written language and passing from daily language to written language. Especially the books prepared for the $6^{\text {th }}$ grade having rich contents in terms of analogies would be useful for creating awareness for figures of speech. Turkish language teachers may provide information for the students against the slang they may encounter on the street defencelessly rather than forbidding it.

In addition to positive sentences, including negative, question, exclamation, conditional, imperative, optative and necessitative sentences would be useful for the comprehension of these sentence types. Configuring performance sequences within the texts within the light of pragmatics would be useful for conducting a more effective reading training about the functional roles during the communication of the statements. Course books are among the most important course materials used in mother language education. Within this context while choosing texts for concerning books the methods of linguistics, semantics, textual linguistics, poetics, semiotics must be utilized and the text preferences should never be left to chance. The name of the author should never be considered as the only reason while choosing the texts of the book. The texts must be analyzed within the frame of certain criterions and considering the structural characteristics the principle of suitableness for the children must be pursued. Including the texts that considering socioeconomic level differences in the course books or presenting these kinds of texts in the course books within a separate part, considering socioeconomic differences in the distribution of the books would be useful for overcoming the problems originating from level differences. 